The Bangladesh Veterinarian (2009) 26(1) : 13 - 16

\title{
Effects of chick separation and feeding on the performance of hens and chicks
}

\author{
M. J. R. Amin ${ }^{*}$, M. A. R. Howlider and M. A. Ali \\ Department of Poultry Science, Faculty of Animal Husbandry, Bangladesh Agricultural \\ University, Mymensingh-2202, Bangladesh
}

\begin{abstract}
A study was conducted to observe the effect of separating chicks from broody hens after hatching, and supplementary feeding, on the performance of broody hens and chicks. Eighteen broody hens incubated 360 eggs of native hens. Broody hens and chicks were divided into three treatment groups; in $\mathrm{T}_{1}$, chicks were not separated, and chicks scavenged with mothers; in $\mathrm{T}_{2}$, chicks were separated at five days and fed ad libitum; and in $T_{3}$, chicks were separated at 10 days and fed ad libitum. Hens in $T_{2}$ and $T_{3}$ received $50 \mathrm{~g}$ feed/hen/day. The interval between end of incubation and first lay was shorter in $\mathrm{T}_{2}$ (36.3 days) and $\mathrm{T}_{3}$ (41.7) than in $\mathrm{T}_{1}$ (55.2). Clutch length was shortest in $\mathrm{T}_{1}$ (12.7 days), medium in $T_{3}$ (15.0) and longest in $T_{2}$ (17.0). There were more eggs/clutch in $T_{2}$ (14.7) and $T_{3}$ (14.3) than in $T_{1}$ (11.5). There were no differences in broody hen's body weight between treatment groups. Mortality of chicks was highest in $\mathrm{T}_{2}(39.6 \%)$, medium in $\mathrm{T}_{3}(33.9)$, and lowest in $\mathrm{T}_{1}$ (21.0). Body weight of chicks was highest in $\mathrm{T}_{2}$, medium in $\mathrm{T}_{3}$ and lowest in $\mathrm{T}_{1}$, except at $1^{\text {st }}$ week of age. It is suggested that separation of chicks and supplementary feeding was beneficial in terms of interval between end of incubation and first lay, clutch length, number of eggs per clutch and body weight of chicks. (Bangl. vet. 2009. Vol. 26, No. $1,13-16)$
\end{abstract}

\section{Introduction}

In Bangladesh, indigenous chickens produce about 35 to 45 eggs per year (Bulbul et al, 1983). Broodiness, rearing of chicks, and feeding are important factors limiting egg production. Huque et al. (1990) observed that separation of chicks from broody hens increased egg production, but he used a limited number of broody hens and chicks. Feed supplementation increased egg production of native poultry (Huque et al., 1992). No comprehensive report on the separation of chicks after brooding is available. The aim of this study was to investigate the effect of separating chicks and feeding on egg production and body weight of broody hens and on the performance of chicks.

\section{Materials and Methods}

The experiment was carried out at Pakkhiya village of Patuakhali district for four months. Hatching eggs of native hens were collected from local farmers and hatched using 18 broody hens. Each hen incubated 20 eggs. After hatching of chicks, broody

\footnotetext{
${ }^{1}$ Livestock Training Institute, Department of Livestock Service, Gaibandha, Bangladesh *Correspondence: E-mail:- amin_rahman2008@yahoo.com
} 
hens and chicks were divided into three groups: in $\mathrm{T}_{1}$ chicks were not separated; in $\mathrm{T}_{2}$, chicks were separated from hens at five days old and fed ad libitum; and in $\mathrm{T}_{3}$ chicks were separated at 10 days old and fed ad libitum.

During incubation every hen was provided with a commercial layer ration "Quality feed" (Quality Feeds Limited, House 14, Road 7, Sector 4, Uttara, Dhaka1230, Bangladesh) @ 50g per day After hatching of chicks, hens in groups $T_{2}$ and $T_{3}$ were supplied Quality feed (Quality Feeds Limited, House 14, Road 7, Sector 4, Uttara, Dhaka-1230, Bangladesh) @ 50g per hen per day. Diet for hens contained 89\% dry matter (DM), $2740 \mathrm{Kcal}$ metabolisable energy (ME), 18\% crude protein (CP), 5\% ether extract (EE), 3\% crude fibre (CF), 1\% Lysine, 0.5\% Methionine, 3.7\% calcium and $0.5 \%$ available phosphorus (AP). Chicks' diet contained 89\% DM, 2950Kcal ME, $19 \%$ $\mathrm{CP}, 5.3 \% \mathrm{EE}, 3 \% \mathrm{CF}, 0.5 \%$ Lysine, $0.4 \%$ Methionine, $1.2 \%$ calcium and $0.45 \% \mathrm{AP}$. Nutritive values were obtained from the manufacturer.

The following parameters were recorded: 1) Broody hen's body weight, 2) Interval between end of incubation and first lay, 3) Clutch length, 4) Number of eggs per clutch, 5) Chick's body weight and 6) Chick's mortality. All recorded and calculated data were used for a Completely Randomized Design. Duncan's New Multiple Range Test was performed to isolate the significant differences between treatment means.

\section{Results and Discussion}

The interval between end of incubation and first lay, clutch length, number of eggs/clutch and mortality of chicks are presented in Table 1 . The interval was shorter $(p<0.01)$ in $T_{2}$ and $T_{3}$ than in $T_{1}$, which are similar to those described by Karim (2005). He suggested that hens from which chicks were separated immediately after hatching and which received highest supplementation (100g/day/bird) laid earliest. Pattern of hormone secretion may be a reason for late laying in hens with chicks (Pampin and Ruiz, 1998). The interval was not different ( $p>0.05)$ between separation at 5 days and 10 days.

Table 1. Performance of hens and mortality of chicks after chick separation and supplementary feeding

\begin{tabular}{l|c|c|c|c}
\hline \multirow{2}{*}{ Traits } & \multicolumn{3}{|c|}{ Treatment (Mean $\pm \mathrm{SD})$} & $\begin{array}{c}\text { Level of } \\
\text { significance }\end{array}$ \\
\cline { 2 - 4 } & $\mathrm{T}_{1}$ & $\mathrm{~T}_{2}$ & $\mathrm{~T}_{3}$ & $* *$ \\
\hline Interval between end of & $55.2 \pm 5.8^{\mathrm{a}}$ & $36.3 \pm 10.1^{\mathrm{b}}$ & $41.7 \pm 8^{\mathrm{b}}$ & \\
incubation and first lay (days) & & & & $*$ \\
Clutch length (days) & $12.7 \pm 2.7^{\mathrm{b}}$ & $17.0 \pm 2.7^{\mathrm{a}}$ & $15.0 \pm 2.4^{\mathrm{ab}}$ & $*$ \\
Number of eggs/clutch & $11.5 \pm 1.5^{\mathrm{b}}$ & $14.7 \pm 0.5^{\mathrm{a}}$ & $14.3 \pm 1.5^{\mathrm{a}}$ & $* *$ \\
Chick's mortality (\%) & $21.0 \pm 3.7^{\mathrm{c}}$ & $39.6 \pm 5.2^{\mathrm{a}}$ & $33.9 \pm 4.7^{\mathrm{b}}$ & $* *$ \\
\hline
\end{tabular}

${ }^{*}, \mathrm{p}<0.05 ;{ }^{* *}, \mathrm{p}<0.01 ; \mathrm{T}_{1}$, chicks not separated from hen, and no supplementary feeding; $\mathrm{T}_{2}$, chicks separated from hen at 5 days old, fed ad libitum and hens received $50 \mathrm{~g}$ feed/day/hen; $\mathrm{T}_{3}$, chicks separated from hen at 10 days old, fed ad libitum and hens received $50 \mathrm{~g}$ feed/day/hen; values with different superscripts in the same row differ significantly. 
Clutch length was shortest $(\mathrm{p}<0.05)$ in $\mathrm{T}_{1}$ and longest in $\mathrm{T}_{2}$. These findings partially agree with Huque et al. (1990), who reported longer clutch length in hens from which chicks were separated at 21 days after hatching than in hens with chicks. The results contradict those of Haque et al. (1991), who stated that there were no significant differences $(p>0.05)$ in clutch length for hens with or without chicks.

The number of eggs per clutch was higher in $T_{2}$ and $T_{3}(p<0.01)$ than in $T_{1}$. Results of longer clutch length and higher egg productions per clutch coincide with the results of Huque et al. (1990), but contradict those of Haque et al. (1991), where the egg production per clutch was not different after separation of chicks. Separation of chicks and balanced diet increased mortality of chicks, in agreement with Huque et al. (1990), but inconsistent with Haque et al. (1991), who reported that mortality was higher in chicks in a traditional management system.

Table 2. Body weight (g) of broody hens and chicks after hatching of chicks for chick separation and feeding

\begin{tabular}{l|c|c|c|c|c}
\hline \multirow{2}{*}{ Traits } & \multirow{2}{*}{$\begin{array}{c}\text { Age } \\
\text { (week) }\end{array}$} & \multicolumn{3}{|c|}{ Treatment (Mean \pm SD) } & Level of \\
\cline { 3 - 6 } & & $\mathrm{T}_{1}$ & $\mathrm{~T}_{2}$ & $\mathrm{~T}_{3}$ & \\
\hline Bignificance \\
Heody & 1 & $1029.2 \pm 76.2$ & $1061.0 \pm 94.8$ & $1031.5 \pm 94.7$ & NS \\
Body & 2 & $1040.0 \pm 75.8$ & $1076.3 \pm 92.6$ & $1044.8 \pm 94.1$ & NS \\
Weight & 3 & $1050.0 \pm 77.7$ & $1092.7 \pm 96.5$ & $1057.5 \pm 94.4$ & NS \\
& 4 & $1060.3 \pm 79.2$ & $1106.8 \pm 95.1$ & $1071.5 \pm 98.6$ & NS \\
& 5 & $1071.0 \pm 80.4$ & $1123.5 \pm 98.2$ & $1085.2 \pm 97.3$ & NS \\
& 6 & $1079.2 \pm 79.9$ & $1140.2 \pm 95.3$ & $1107.8 \pm 99.3$ & NS \\
& 7 & $1089.2 \pm 78.7$ & $1155.0 \pm 91.6$ & $1111.0 \pm 96.6$ & NS \\
Chick's & 1 & $32.5 \pm 2.2$ & $35.1 \pm 3.0$ & $32.7 \pm 1.6$ & NS \\
Body & 2 & $43.0 \pm 1.7^{\mathrm{b}}$ & $54.1 \pm 5.0^{\mathrm{a}}$ & $50.4 \pm 1.6^{\mathrm{a}}$ & $* *$ \\
Weight & 3 & $80.2 \pm 8.4^{\mathrm{b}}$ & $89.5 \pm 6.8^{\mathrm{a}}$ & $80.3 \pm 2.4^{\mathrm{b}}$ & $*$ \\
& 4 & $88.1 \pm 3.7^{\mathrm{c}}$ & $109.8 \pm 8.7^{\mathrm{a}}$ & $102.0 \pm 4.4^{\mathrm{b}}$ & $* *$ \\
& 5 & $102.3 \pm 3.2^{\mathrm{c}}$ & $129.8 \pm 5.75^{\mathrm{a}}$ & $122.97 \pm 1.9^{\mathrm{b}}$ & $* *$ \\
& 6 & $128.8 \pm 3.2^{\mathrm{c}}$ & $160.4 \pm 4.1^{\mathrm{a}}$ & $151.4 \pm 1.6^{\mathrm{b}}$ & $* *$ \\
& 7 & $154.6 \pm 5.2^{\mathrm{c}}$ & $160.4 \pm 7.3^{\mathrm{a}}$ & $192.3 \pm 2.3^{\mathrm{b}}$ & $* *$ \\
& 8 & $191.7 \pm 7.9^{\mathrm{c}}$ & $221.1 \pm 3.2^{\mathrm{a}}$ & $213.4 \pm 5.3^{\mathrm{b}}$ & $* *$ \\
\hline
\end{tabular}

NS, Non Significant $\mathrm{p}>0.05 ; *, \mathrm{p}<0.05 ;{ }^{*}, \mathrm{p}<0.01^{*} ; \mathrm{T}_{1}$, chicks not separated from hen and no supplementary feeding; $\mathrm{T}_{2}$, chicks separated from hen at 5 days old, fed ad libitum and hens received $50 \mathrm{~g}$ feed/day/hen; $T_{3}$, chicks separated from hen at 10 days old, fed ad libitum and hens received $50 \mathrm{~g}$ feed/day/hen; values with different superscripts in the same row differ significantly 
The body weight of broody hens and chicks in the three treatments are shown in Table 2. Chick separation and feeding did not affect broody hens' body weight significantly ( $p>0.05)$. This result is not consistent with Karim (2005). He observed that hens whose chicks were separated earlier and received highest feed supplementation (100 g/day/bird) had remarkably higher weight than hens who received no supplementation and whose chicks were separated late. Variability of nutrients obtained from scavenging may be the reason why the results of this study contradict Karim (2005).

Except at $1^{\text {st }}$ week of age, body weight of chicks was highest in $T_{2}$ and $T_{3}$, as reported by Huque et al. (1990). They found higher body weight in native chicks at 10 weeks of age separated at 7 days from the broody hens and given improved diet than in a traditional scavenging system. But the findings in this study do not support the finding of Haque (1990) where no significant difference $(p>0.05)$ was observed in body weight of chicks reared under improved and traditional systems.

It is concluded that separating the chicks at 5 and 10 days old from the hens and feeding balanced ration led to a shorter interval between end of incubation and first lay, longer clutch length and more eggs per clutch, and resulted in better performance.

\section{References}

Bulbul SM 1983: More protein for the undernourished through a village poultry project. In: Maximum livestock production from minimum land (Edn. Davis CH, Preston TR, Haque M, Sadullah M). Proceeding of the $4^{\text {th }}$ seminar held at Bangladesh Agricultural University, Mymensingh, Bangladesh. p. 67-69.

Haque ME 1990: A study on the performance of native chickens and their mother hens with or without chicks under village condition. MSc Thesis, Department of Poultry Science, Faculty of Animal Husbandry, Bangladesh Agricultural University, Mymensingh Bangladesh.

Haque ME, Hamid MA, Howlider MAR, Haque QME 1991: Performance of native chicks and hens reared together or separately under rural conditions of Bangladesh. The Bangladesh Veterinarian 8 11-13.

Huque QME, Haque ME, Ragor EM 1990. The effect of chick separation on the productivity of the hen and chick. Asian-Australasian Journal of Animal Sciences 3 121-123.

Huque QME, Ukil MA, Hossain MJ, Haque ME 1992: Nutritional status of scavenging hens in Bangladesh. Bangladesh Journal of Training and Development 7 35-43.

Karim MR 2005: Chick separation and feed supplementation to induce the broody hens in egg production. MS Thesis, Department of Poultry Science, Faculty of Animal Husbandry, Bangladesh Agricultural University, Mymensingh, Bangladesh.

Pampin M, Ruiz C 1998: Characterization of semirustic fowls. Broodiness. Revista Cubana de Ciencia Avicola 22 69-71. 